\title{
NEGRO TOWER: DOCUMENTATION, CONSERVATION, AND RESTORATION
}

\author{
J. García-León, P.E. Collado Espejo, F. J. Jiménez González
} Dpto. Arquitectura y Tecnología de la Edificación, Universidad Politécnica de Cartagena. Cartagena, España
josefina.leon@upct.es, pedroe.collado@upct.es, franciscoj.jimenezgonzalez@gmail.com

\section{Commission II, WG II/8}

KEY WORDS: Topography, Terrestrial Laser Scanner, Photogrammetry, Conservation, Restoration.

\begin{abstract}
:
The Negro Tower or Arráez Tower, in El Algar (Cartagena, Spain), dates from 1585. This tower was part of an extensive network of watch and defense towers built along the coastline of Murcia between the sixteenth and seventeenth centuries. It is an inland rural tower, in visual contact with the coastal towers. Its objective was to receive and transfer warnings from onshore towers to protect the population, especially farmers. The tower is protected as a monument but is currently in a dilapidated state of conservation. Therefore, this building has been chosen as the object of an integral study, which can serve as a reliable basis for its correct conservation and restoration. Through historical analysis, light has been shed upon the evolution of the Tower from the social, cultural, and architectural points of view. The graphic documentation has been made using digital photogrammetry and a 3D laser scanner, compatible with classical topography. Based on all this information, an integral project of consolidation and volumetric recomposition of the tower has been proposed. As a result of this research, we intend to contribute to the conservation and recovery of the heritage value of the Tower, as well as the integration of the historic monument in its natural environment.
\end{abstract}

\section{INTRODUCTION}

Between 1568 and 1571, the Mediterranean had become a natural frontier between the Spanish and Turkish empires causing Spanish coasts to suffer permanent attacks from Turkish-Berber corsairs from North Africa (Velasco, 2017).

The numerous attacks by pirates from the Maghreb showed that the Spanish coast, especially the Murcian and Mallorcan shorelines, were not properly defended. In light of the developments in the region, King Philip II began an ambitious project consisting of the construction of an extensive network of watch and defense towers on the Mediterranean coastline, especially on the most often besieged seashores. This network of coastal towers, which were built between the sixteenth and seventeenth centuries, has a dual mission: to monitor and defend the coastal waters, and to serve as a warning to the inhabitants of the area. To do this, the towers were armed; that is, they had one or more pieces of artillery to enable them to shoot at the ships on their approach to the coast.

The Crown had commissioned the military engineer of Italian origin, Giovanni Battista Antonelli to undertake an ambitious project of fortification and defense of the entire Mediterranean coastline, combining the construction of defensive towers with urban fortifications at the end of the 1560s (Gómez \& Munuera, 2002). After a first phase of field reconnaissance and the planning of the number of defensive towers needed, the best location for these constructions would be determined in order to best monitor and defend the entire Mediterranean coast; from Catalonia to the Bay of Cádiz, including the Majorcan coasts.

The fundamental characteristic of this defense network was the visibility and coordination among the different towers. The success or failure of the Berber incursions depended, to a large extent, on the rapidity of the warning between the coastal and inland towers. Therefore, the network of watchtowers and seashore defense would be based on three types of constructions. A first type would be the watchtowers directly on the coastline, which formed the first line of defense against enemy incursions. A second group was the fortress towers, located inland, but in direct visual contact with the watch towers on the coastline. These constructions were used as refuges and safe houses for the population and agricultural settlements that were dispersed in small areas, far from the protection of the most important castles or fortresses. Therefore, there was an internal network of constructions permitting the inhabitants of small settlements to shelter and defend themselves from hostile forces. The third group were the interior towers, far from the coast, which would provide surveillance and protection to more important populations (mostly agricultural and mining areas), which could also be attacked by the North African corsairs (Gómez, 1997) and (Gómez et al. 2003).

Unfortunately, this important historical architectural and cultural heritage of the Mediterranean coast has lost one of its main characteristics: unity. Many of the towers have disappeared and several of them have been abandoned (Cámara, 1990).

In addition, there is almost no documentation, making their reliable reconstruction impossible. To carry out accurate documentation of the volumetric and constructive reality of the towers, it is possible to use two techniques; terrestrial photogrammetry and laser scanner measurement, in a complementary way. The data provided by photogrammetry and laser scanning is essential for the documentation of heritage and artistic pieces (Yastikli, 2007). Thus, other aspects can be analyzed, which by traditional procedures would be far more difficult to obtain.

The combination of contemporary technologies with traditional analysis and procedures can offer a wide range of possibilities to the documentation of cultural and architectonical heritage, as 
has been proven by previous investigations (Remondino, 2011): The accurate modelling of complex shapes is no longer as difficult as it was in the past. These digital models can be used by interdisciplinary researchers, taking great advantage of modern techniques and instruments.

The use of digital 3D simulation as a reliable enduring reference for restoration and maintenance practice through an Information System (IS) has been widely demonstrated (Apollonio et al., 2017).

The Tower is affected by the Law of Cultural Heritage of the Region of Murcia, so that its total or partial reconstruction should enhance "effects of perception of cultural values and of the good of the whole", with the additions being differentiated "in order to avoid misleading impressions." Therefore, the intervention is proposed with three basic objectives: to consolidate and rebuild the building; to make it as accessible and safe as possible; and to give it cultural use. Likewise, the scientific methodology of analysis and performance criteria and execution control must be absolutely respectful of the historical, architectural, social, and cultural values that the Tower represents, subtly differentiating old and new materials (Collado et al., 2018).

The objective of this research is to obtain reliable historical and graphic documentation of the Negro Tower, using threedimensional digital models. Thus, with knowledge of the constructive characteristics of the tower and its state of conservation, we would be able to make an intervention proposal focused on the integral recovery of the tower and the restoration of its value. In this process, the knowledge and diffusion of this cultural asset would be increased.

\section{STUDY OBJECT}

\subsection{The Negro Tower}

The Negro Tower or Arráez Tower, in El Algar (Cartagena, Spain), dates from 1585 (figure 3). This tower was part of an extensive network of watch and defense towers, built along the Murcian coast between the sixteenth and seventeenth centuries (García-León et al., 2019). It is a rural, inland tower, but in visual contact with the coastal towers. Its purpose was to receive and transfer warnings from the coastal towers in order to protect the population, especially farmers.

Originally, the tower was freestanding, but nowadays it is part of a private rural house. It is located in the surroundings of the Mar Menor area. This Sea is a lagoon with a surface of $135 \mathrm{~km}^{2}$, and five volcanic islands in its interior (figure 1). This Sea was created by La Manga, which is a coastal strip formed during the Cenozoic era in the southeastern Iberian Peninsula. La Manga is $22 \mathrm{~km}$ long and has a variable width of between 100 and 1,200 $\mathrm{m}$. In its coastal perimeter, it has $73 \mathrm{~km}$ of coastline, with beaches of transparent and shallow waters. In ancient times, the coastal strip of La Manga did not completely close the passage to the Mar Menor from the Mediterranean Sea, which allowed the navigability of the lagoon during the period of Phoenician, Greek and Roman colonization.

In La Manga during the Middle Ages, the first fishing weirs were installed. During the sixteenth century, four coastal towers were built along it, as a defense against the Berber pirates. At the end of that century, its vegetation, mainly juniper, was removed to prevent pirates from using the vegetation for cover during ambushes. Over the second half of the 20th century, it was urbanized, and is now an important coastal tourist area.

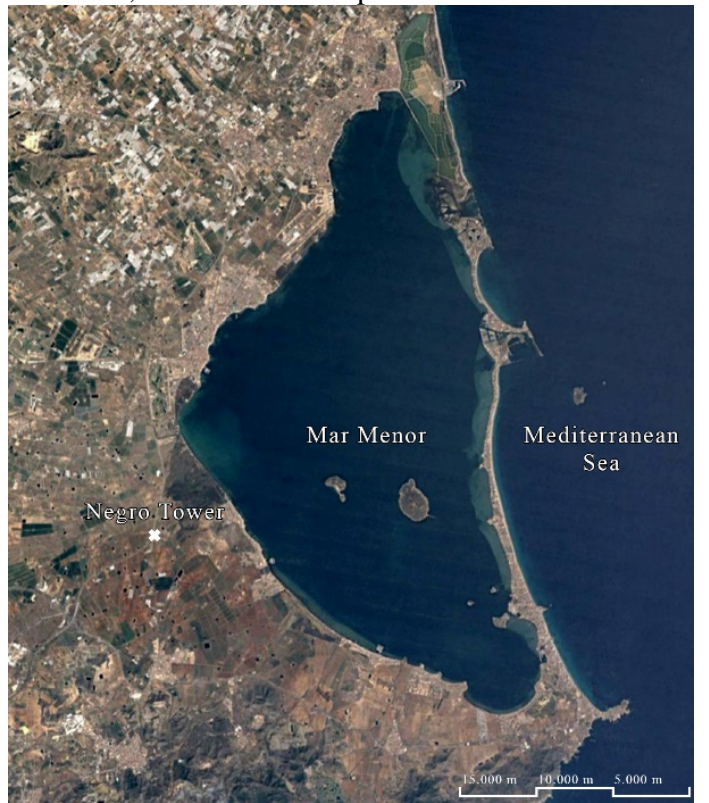

Figure 1. Location of the Negro Tower within the Mar Menor.

\subsection{Material and constructive analysis.}

The Torre del Negro is an example (in design, materials, and construction systems) of the fortifications that were built throughout the sixteenth century for the defense of the coastline of Murcia (Rubio, 2000). As a tower built in a rural environment and not directly on the coast, its basic function was to monitor and warn, principally farmers of pirate invasions (Pérez, 2007). For this reason, it did not have a properly defensive function, but served rather as a safe house, which is reflected in its constructive system. It is structured on three floors with a flat rooftop, with access from the interior, and a total built area of $234.96 \mathrm{~m}^{2}$. The tower has a square base, with an area of $66.84 \mathrm{~m}^{2}$ on the ground floor, and a slight inward inclination average of $5^{\mathrm{g}}$ (figure 2). Therefore, it forms a truncated pyramid; the roof has a surface of $51.33 \mathrm{~m}^{2}$, with an average height of $12.34 \mathrm{~m}$ up to the rooftop.

The tower was built following a structural system of loadbearing masonry walls of carved stone and lime mortar (Velasco, 2017). The thickness of these walls varies between $1.75 \mathrm{~m}$. at the base and $0.64 \mathrm{~m}$. at the rooftop. The horizontal structure was resolved with a stone vault, with earth and lime filling, on the ground and first floors, and a traditional floor (wooden beams and solid interwoven brick), for the upper deck. This structural system, which is also used for the watchtowers and defensive towers of the coast, provides great stability and resistance to the whole building. Wall openings and corners were made of solid brick (except on the ground floor, where the entire wall is made of masonry).

This type of construction was designed to promote the repopulation of the area, so the protection of the inhabitants of the area in case of attack was paramount. Therefore, access to the tower is independent on the ground and first floors, with no direct communication between them. Access to the first floor is possible using a portable ladder. The communication between the first floor, the second floor, and the roof (accessible roof to be able to visualize the surroundings) was solved with an internal, spiral staircase, made of stone and located in the northwest corner. All the walls, both inside and outside, were 
covered with a lime and plaster mortar, so originally, the tower would stand out in the landscape, due to its bright white façade.

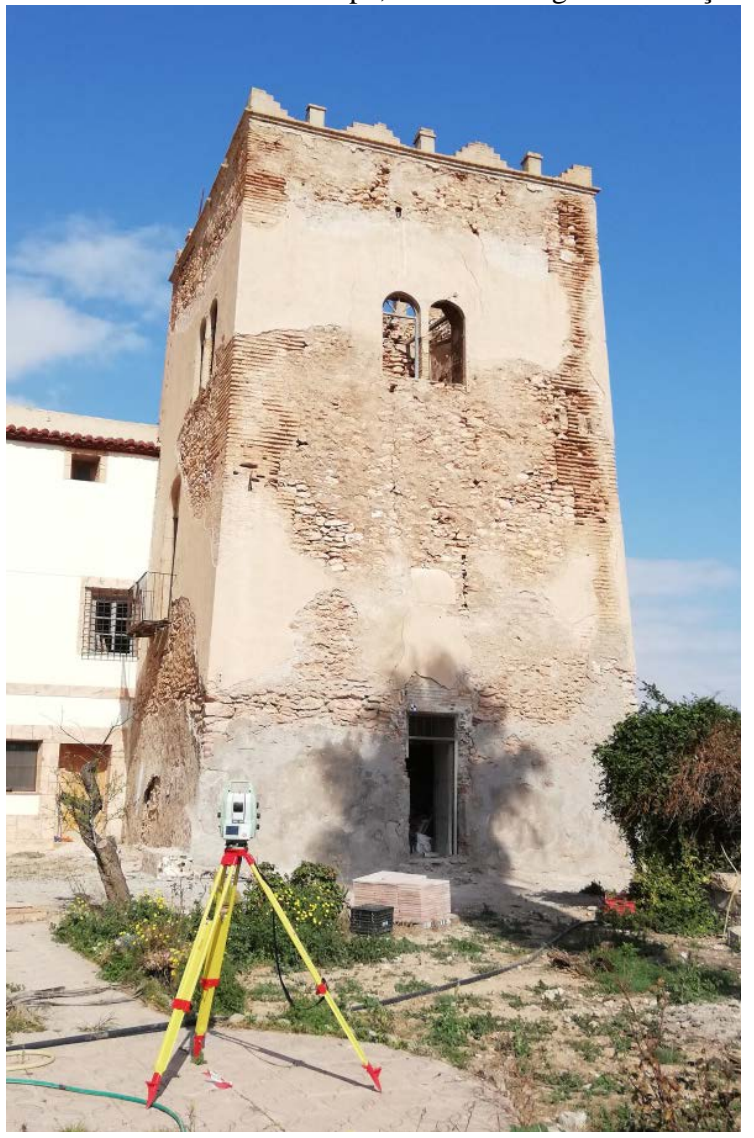

Figure 2. West façade attached to the rural house and South façade of the Negro Tower during the data collection phase.

\subsection{State of conservation.}

The current state of conservation of the Negro Tower is very critical; it is practically in ruins. However, it is a protected monument as a BIC (Cultural Heritage Asset) according to the first transitory provision of the Law 4/2007 of Cultural Heritage of the Region de Murcia (BORM, 2007), so it must be recovered and restored to guarantee its recognition and conservation.

The main factors in its deterioration are the lack of adequate maintenance and extensive exposure to meteorological elements, which are very aggressive in this coastal area (Collado et al., 2018). This has favored the erosion of the entire envelope, with loosening of the plaster (especially on the ground floor and North and South façades), and some loss of section due to the detachment of masonry (North façade). The solid bricks of the corners and jambs present disaggregation and sandification in specific areas (very noticeable in the South façade). The vault on the ground floor is in good condition, but from the first floor, the entire interior is hollow, having collapsed more than three decades ago, as shown in various documents (General Direction, 2019). The horizontal structure (first floor vault and second floor slab) has disappeared. Part of the rubble is still on the ground floor vault. (figure 5). Therefore, the entire distribution partition, interior staircase and deck have been lost. The woodwork (doors and windows) has also disappeared. Only a metal grid and the balcony railing remain on the first floor, although both forging elements exhibit oxidation and corrosion. The rest of the wall openings (windows and access door on the first floor) are totally clear.

Fortunately, a marble plaque still exists and is in good condition over the entrance door to the ground floor (South façade), with the inscription: " REYNANDO LA MAG. DEL REY DON FELIPE SR. DO DESTE JUAN GINER PAGADOR DE SUS ARMADAS Y GALERAS Y REGIDOR DE CARTAGENA MANDÓ HAZER ESTA TORRE AÑO 1585 ". However, the sundial that was on the southwest corner has been lost during recent decades (figure 3).
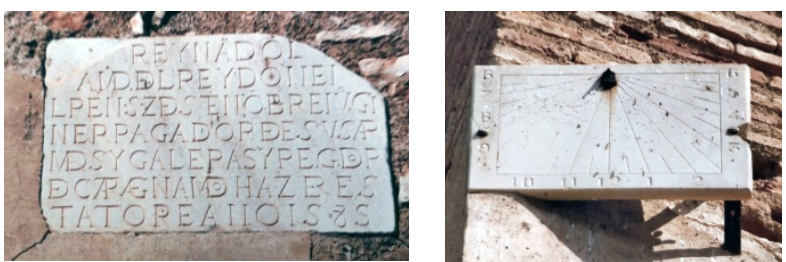

Figure 3. On the left, the marble plaque of the South facade, which is still preserved, where the date of the construction of the tower and the person who funded it appear. On the right, an image of the sundial located on the southwest corner. (General Direction, 2019).

\section{METHODOLOGY}

The process followed is detailed up to obtaining the precise digital model and the intervention proposal represented graphically.

\subsection{Data Collection}

The on-site data collection was performed with the Leica Nova MS50 multi-station (figure 5), with eight stations linked by classical topography (figure 4), obtaining a point cloud with a density of $1 \mathrm{~cm}$ at a variable distance - between $8.00 \mathrm{~m}$ and $18.00 \mathrm{~m}$ - during February 2019, located at different heights (table 1). Also, 37 tie and control points were taken from the different stations and distributed throughout the surface of the model; some pre-marked and others natural, to perform the verification of the accuracy in the final model obtained. A total of 17 million points were recorded, which have been dumped in the Infinity software and refined in it. In addition, photographs were taken using different methods. Firstly, they were taken with the camera integrated into the laser scanner, to color obtained cloud points. Secondly, photographs were taken with a Canon EOS 1100D reflex camera with a $35 \mathrm{~mm}$ lens on a steady tripod. RAW format was used to make the white balance adjustment with the Xrite ColorChecker color chart, which allowed optimal color, since they were used to give the final texture to the model.

\begin{tabular}{|c|c|c|c|c|}
\hline$\frac{\text { Station }}{\underline{\text { Point }}}$ & $\begin{array}{c}\text { Coord. X } \\
(\mathrm{m} .)\end{array}$ & $\begin{array}{c}\text { Coord. Y } \\
(\mathrm{m})\end{array}$ & $\begin{array}{c}\text { Coord. Z } \\
(\mathrm{m})\end{array}$ & $\begin{array}{c}\text { Dist. from the } \\
\text { cloud point at } \\
1 \mathrm{~cm}(\mathrm{~m})\end{array}$ \\
\hline A & 100.00 & 100.00 & 10.00 & 18.00 \\
\hline B & 110.12 & 92.11 & 9.60 & 15.00 \\
\hline C & 132.76 & 107.45 & 10.13 & 18.00 \\
\hline D & 126.45 & 115.19 & 10.24 & 15.00 \\
\hline E & 119.71 & 105.37 & 14.40 & 8.00 \\
\hline G & 119.00 & 106.05 & 10.06 & 8.00 \\
\hline J & 118.15 & 112.31 & 13.19 & -- \\
\hline P & 118.38 & 102.09 & 10.09 & -- \\
\hline
\end{tabular}


Table 1. Local coordinates of the station points used, linked through classic topography

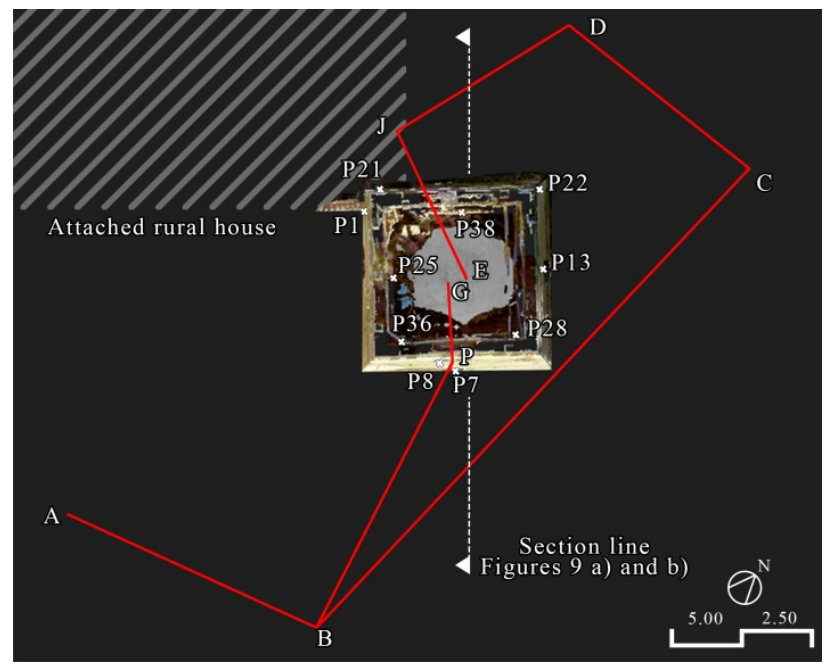

Figure 4. View from above of the stations points connected by classical topography together with the red line and the control points used, measured in the Negro tower.

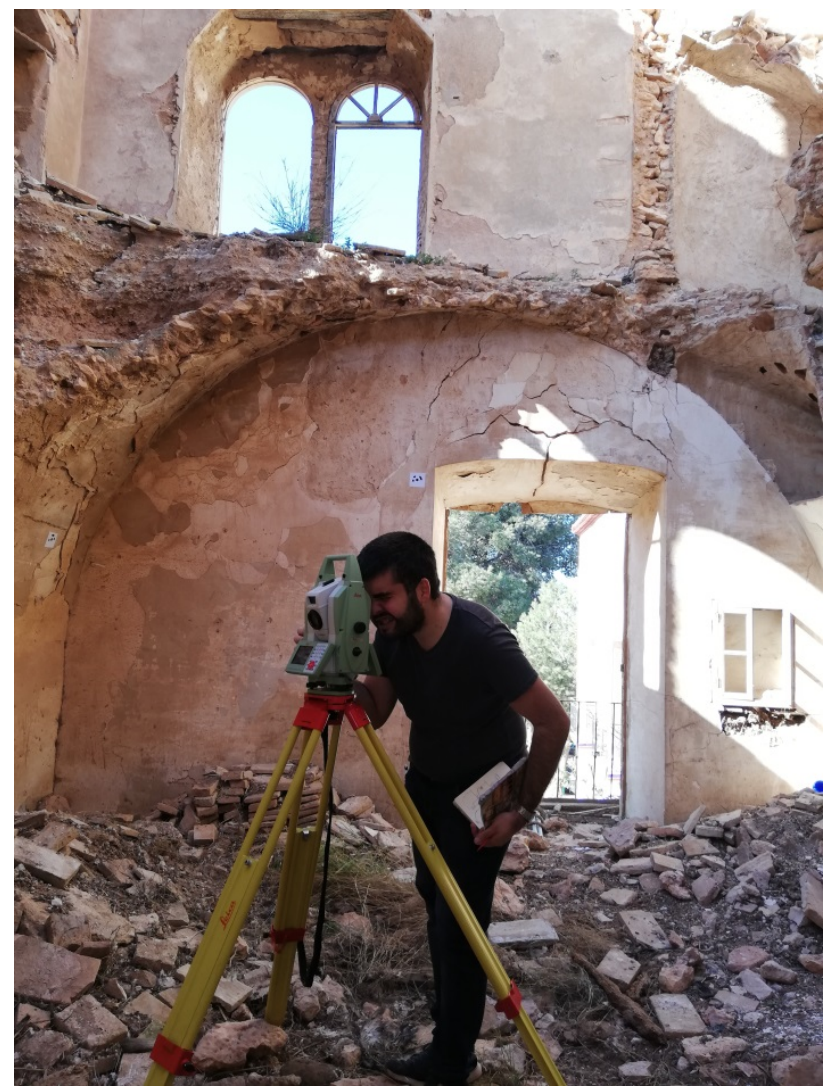

Figure 5. Data collection with a Multistation Leica Nova MS50 on the first floor. Collapsed vault and rubble can be noticed.

\subsection{Visibility studies among towers}

The visibility among the different towers was crucial for the proper functioning of the network. The effectiveness of the defensive system has been verified using the Digital Terrain Models of the Spanish National Geographical Institute (2019). A visibility study has been carried out, introducing the position of the existing towers in a layer of points (García-León et al., 2019). Using the free Geographic Information System software
QGIS, it was demonstrated that visibility among the towers at a distance of $20 \mathrm{Km}$ existed, with several of them simultaneously visible. Regarding our case of study -according to figure 6-, from the Negro Tower, four coastal towers located outside the Mar Menor would have been visible. They are the Pinatar Tower, the Encañizada Tower, Estacio Tower and San Antonio Tower, all of which have disappeared. Two fortress towers; as the Rame Tower and Garciapérez Tower would also have been visible.

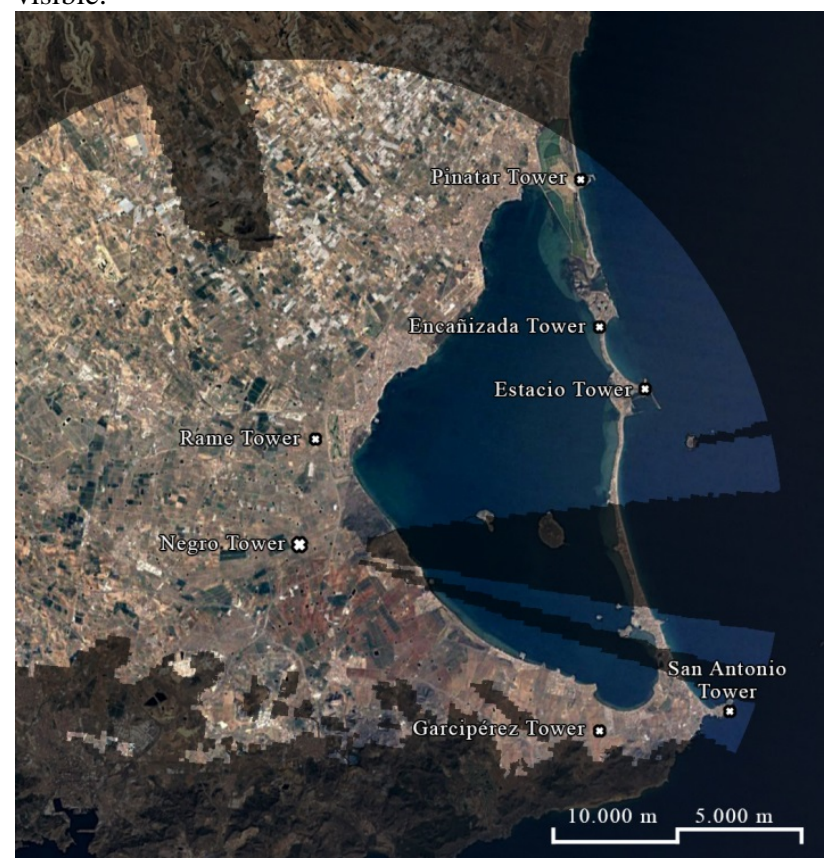

Figure 6. Image from the visibility study among coastal towers and fortress towers with the Negro Tower as the origin.

\subsection{D Model}

After the data dump in the Infinity program, the best adjustment was made between the point clouds in 3D Reshaper software. After cleaning the clouds and optimizing the mesh, existing gaps have been closed, and the crowning elements of the cover have been modelled with the Blender program, due to the lack of information about them in the point clouds. With the final model obtained, the texture has been applied with the images made, using the PhotoScan program, and the following data have been measured and obtained from it (figure 7):

- Height of Windows and dimensions:

o Entrance at ground floor on South façade: $2.57 \mathrm{~m}$. high x $1.12 \mathrm{~m}$. wide.

o Windows with semicircular arch: $1.75 \mathrm{~m}$. high $\mathrm{x}$ $0.75 \mathrm{~m}$. wide.

o Balcony on first floor: $3.25 \mathrm{~m}$. high x $1.55 \mathrm{~m}$. wide.

o Rectangular window on West façade: $1.10 \mathrm{~m}$. high $\mathrm{x} 0.90 \mathrm{~m}$. wide.

o Flared window on North façade: $2.25 \mathrm{~m}$. high $\mathrm{x}$ $0.80 \mathrm{~m}$. wide.

- Height between floors (figure 9a)

o Ground floor and first floor: $4.62 \mathrm{~m}$

o First floor and second floor: $3.81 \mathrm{~m}$.

o Second floor and rooftop: $3.68 \mathrm{~m}$.

- Thickness of walls

o South façade: $1.77 \mathrm{~m}$. at the base, $0.63 \mathrm{~m}$. at the rooftop.

o West façade: $1.71 \mathrm{~m}$. at the base, $0.67 \mathrm{~m}$. at the rooftop.

o North façade: $1.85 \mathrm{~m}$. at the base, $0.64 \mathrm{~m}$. at the rooftop.

o East façade: $1.65 \mathrm{~m}$. at the base, $0.62 \mathrm{~m}$. at the rooftop. 
- Wall inclination

o Average inward: $5.00^{\mathrm{g}}$

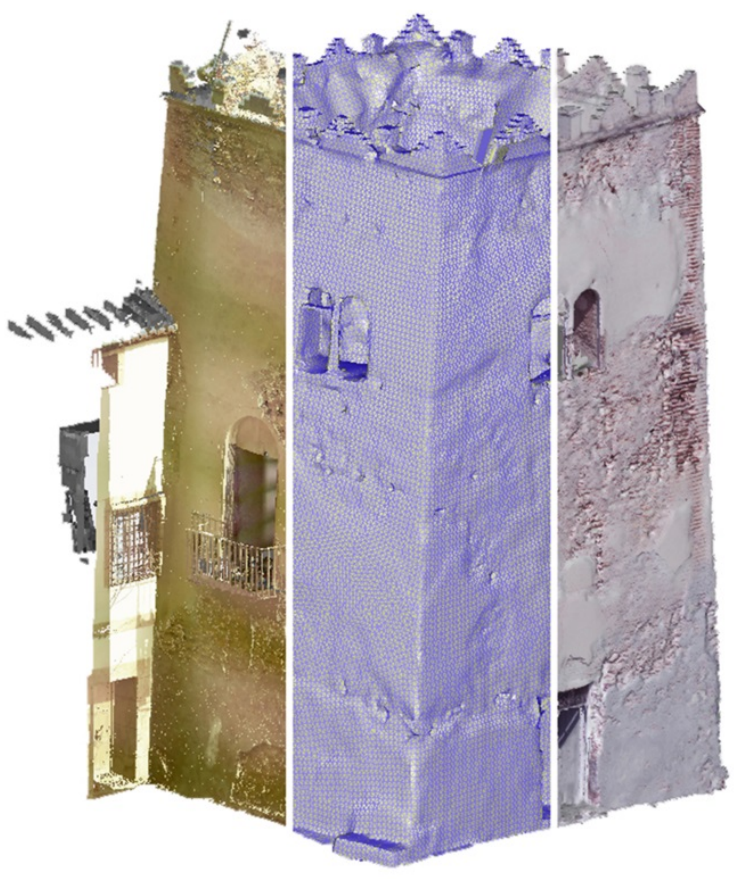

Figure 7. Point cloud, triangle mesh and textured of the model of the Negro Tower, processed with 3D Reshaper.

\subsection{Model Accuracy.}

For the calculation of the accuracy obtained in the model, it is necessary to check its quality, with this intention the control points measured by topography in situ in the tower were compared with their equivalents in the generated model. The difference between them has been calculated (table 2).

\begin{tabular}{|c|c|c|c|}
\hline $\begin{array}{c}\text { Reference } \\
\text { Point }\end{array}$ & $\begin{array}{c}\text { Variation in } \\
\text { Coord. X (m) }\end{array}$ & $\begin{array}{c}\text { Variation in } \\
\text { Coord. Y (m) }\end{array}$ & $\begin{array}{c}\text { Variation in } \\
\text { Coord. Z (m) }\end{array}$ \\
\hline P1 & 0.03 & 0.03 & 0.03 \\
\hline P7 & 0.01 & 0.05 & 0.03 \\
\hline P8 & 0.02 & 0.02 & 0.04 \\
\hline P13 & 0.01 & 0.00 & 0.01 \\
\hline P21 & 0.01 & 0.01 & 0.05 \\
\hline P22 & 0.01 & 0.01 & 0.01 \\
\hline P25 & 0.00 & 0.03 & 0.02 \\
\hline P28 & 0.01 & 0.04 & 0.01 \\
\hline P36 & 0.02 & 0.02 & 0.04 \\
\hline P38 & 0.01 & 0.00 & 0.00 \\
\hline
\end{tabular}

Table 2: Calculation of model accuracy though control points.

The errors are in the range of centimeters and the quadratic composition of the errors gives a maximum three-dimensional positional error of $5 \mathrm{~cm}$, and its average $3 \mathrm{~cm}$. Therefore, the accuracy reached is $3 \mathrm{~cm}$ in the Negro tower model generated.

\subsection{Volumetric and Architectonic Recomposition.}

The ultimate purpose of this integral analysis is the rehabilitation of the tower, its correct conservation, and the enhancement of its use as a cultural reference within the Mar Menor area. Therefore, the proposed criteria and methodology of intervention are focused on the integral recovery of the Tower and its value for the enjoyment of the population and visitors. This rehabilitation would allow the construction to become a cultural and tourist asset, also contributing to the improvement of the unique natural space and landscape of the Mar Menor, where it is located.

Based on the current real model obtained in 3D Reshaper, the Blender modelling program has been used to incorporate the constructive solutions for the volumetric recomposition of the Tower. The intervention proposal incorporates the stone vault of the second floor, the flat slab on the rooftop, the interior solid brick staircase, as well as a new external spiral staircase to access the first floor (figure 8).

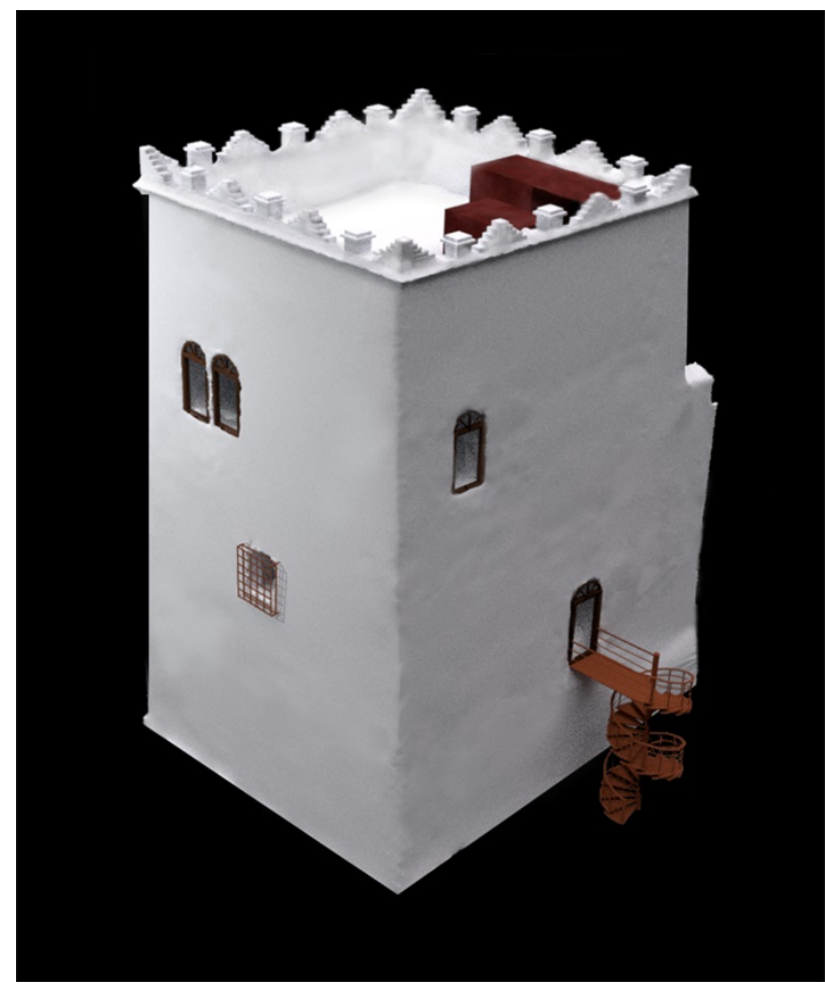

Figure 8. Graphic proposal of the intervention Project.

Firstly, the consolidation and recomposition of the building volumetrically is proposed. Structural walls do not present major deterioration, so the intervention proposal is limited to basic cleaning processes, the elimination of biodeterioration and deteriorated coatings, the consolidation (filling with masonry similar to the original) and application of new exterior plaster (lime mortar covering the existing white layer), and new plaster in the interior. To protect the exterior walls, a final hydrofugation is proposed, as they are exposed to aggressive elements in this coastal area. The reintegration of all the missing elements has been considered with traditional materials (stone, brick and wood) and construction systems. The reconstruction of the vault on the first floor (with solid brick), the wooden floor on the rooftop, and the interior spiral staircase are proposed. 


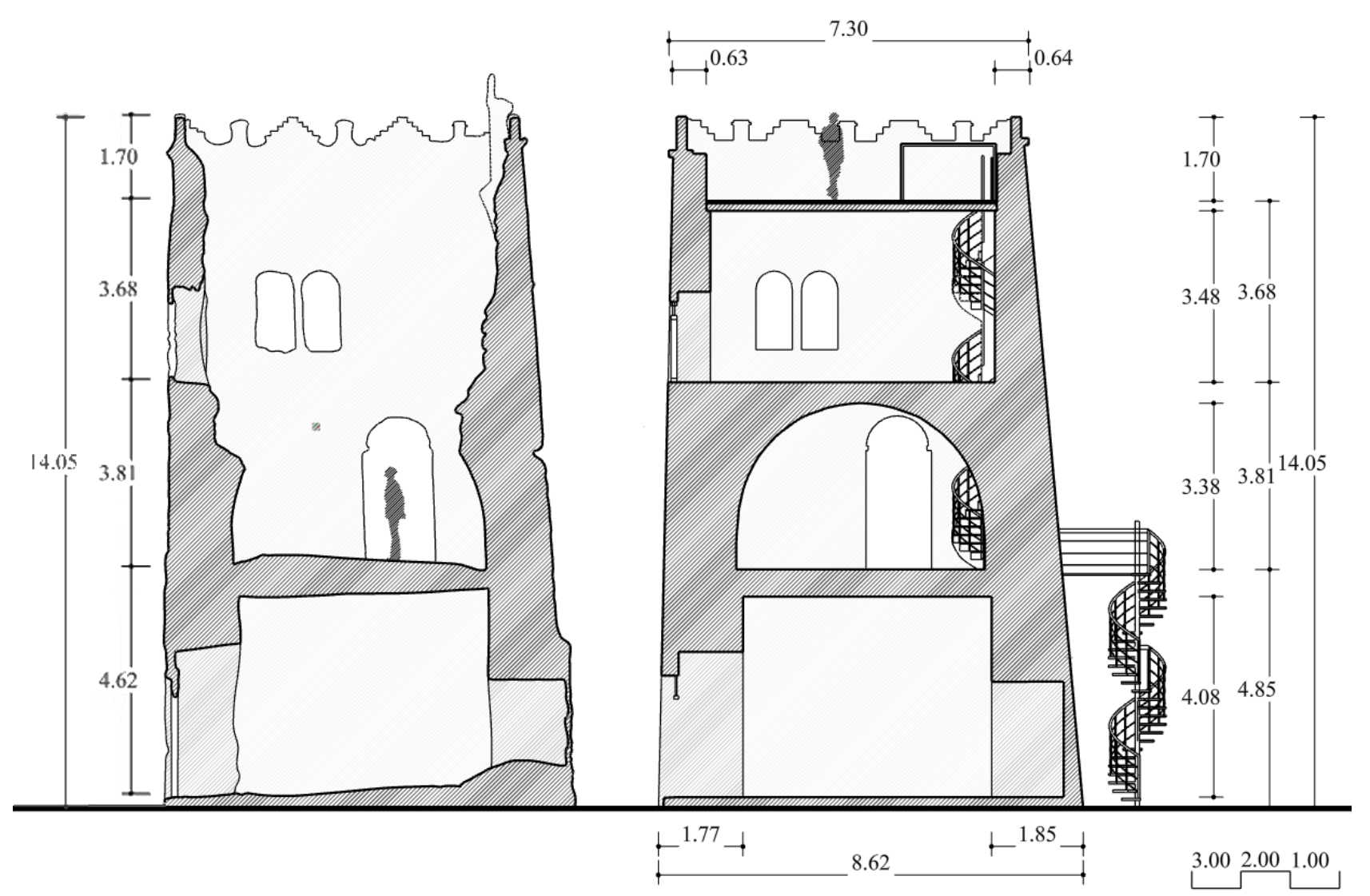

Figure 9. a) Sections of the state current of the Negro Tower and b) proposed state of the Negro Tower.

The eroded solid bricks of the corners and jambs will be eliminated and new bricks of similar characteristics to the original ones will be put in their place. It is necessary to clean and protect the grid and metal railings, as well as design and place new woodwork in the access doors, windows, and balcony. Finally, the complete rebuilding of the rooftop is planned, recovering the unique battlements that crowned it. To access the roof, several small boxes have been designed, made of weathered steel, to give the access a waterproof cover (figure $9 \mathrm{~b})$.

Secondly, the intervention aims to improve the current conditions of accessibility to and security of the building. To achieve this goal, an access path from the nearest road to the tower has been designed, and the immediate surroundings of the tower will be reconditioned. The design of a pleasant green area that invites visitors to walk, rest, recognize, and enjoy this exceptional natural landscape that is within the environment of the Mar Menor is intended. The ground floor of the Tower is accessible by the existing door, but to access the first floor, an external staircase is proposed. Obviously, universal accessibility is not possible with this solution, but we must bear in mind that it is a historical construction, and the intervention must try to recover the original image without altering its architectural configuration. For this reason, weathered steel is proposed as the material for this starcase, with the aim of not excessively altering the exterior image of the tower.

With the objective of improving readability, it is proposed to provide the inside of the tower with informative panels that would explain the historical context of its construction and the documentary, social, and cultural importance of these buildings, as well as audiovisual material from the generated models themselves (García-León et al. 2018).

\section{RESULTS Y CONCLUSIONS}

The results obtained in this research have principally been the following:

- The visibility among the towers has been checked, taking into account the topography of the area. Not only between the Negro Tower and the coastal towers of the Mar Menor, but also between the study tower and other fortress towers. This fact was fundamental for the proper functioning of the defensive system (figure 6).

- Through the modelling of the current tower, wall openings have been measured, as well as the heights of each floor and the characteristics of the entire construction. It has been proven that the windows and balconies are much larger than the original openings, which would probably be windows of a smaller size and flared type (figure 9a).

- The historical and graphic documentation of the tower has been obtained, thus ascertaining the general characteristics of the construction such as the types of vaults and staircases, and also measuring areas and heights, the thicknesses of the walls, and the exact inclination of the whole envelope (figure 9a). 

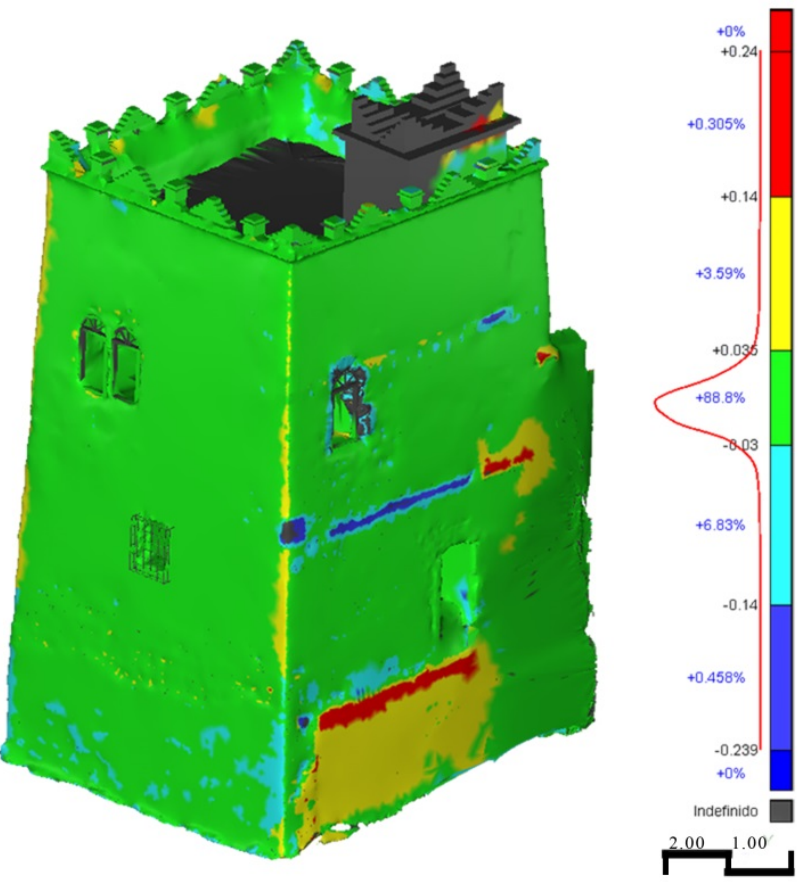

Figure 10. Differences between the current state of the Tower and the ideal state of the North and East façades.

- A volumetric analysis has been carried out between the tower in its current state and the ideal theoretical model, showing the deterioration suffered in the North façade, where a slab of the annexed house was embedded, and the general deterioration of the façades and various openings (figure 11).

- An intervention project has been proposed based on a complete comprehensive analysis (historical, graphic, architectural, material, cultural, and the state of conservation of the Tower) to project its architectural recomposition, from knowledge and absolute respect to its monumental entity (taking into consideration the recomposition criteria established in current legislation), as well as the improvement of its accessibility (figure 8).

- The Heritage Value of the tower has been highlighted, considering that the best way to ensure its conservation is the provision of a new use. Therefore, the new function must necessarily be respectful and completely compatible with all the values that represent and characterize these unique historical buildings. A musealization is proposed to turn it into a historical and cultural asset. The tower would be used as a real example of the importance of the defensive system designed by the kings Charles I and Philip II in the repopulation of the entire coastal strip of the Mediterranean, and in particular, in the Region of Murcia.

- To aid in its diffusion as one of the towers of the sixteenth century, the Tower must be shown as a real example of a rural tower or safe house, of the several that were part of the network of watchtowers and defensive towers, built between the sixteenth and seventeenth centuries for the defense of the Murcian coast (Cámara, 1991). Therefore, once the volumetric and architectural recomposition has been carried out, the Tower must be considered as a living patrimonial document, which should be recognized, visited, and enjoyed.
These networks of rural interior towers were vital to permit the repopulation of these farmlands. Therefore, we must disseminate knowledge about them and promote their restoration as a didactic, social and cultural resource. The best way to achieve this is through the musealization of the Tower and the diffusion of research through virtual pages or through the creation of videogames.

The incorporation of the Tower into the wide patrimonial and cultural assets of Cartagena and the municipalities of the Mar Menor is proposed.

\section{REFERENCES}

Apollonio, F. I.; Ballabeni, M.; Bertacchi, S.; Fallavollita, F.; Foschi, R.; Gaiani, M., 2017. From documentation images to restauration support tools: a path following the Neptune fountain in Bologna design process. Geomatics \& restoration Conservation of Cultural Heritage in the Digital Era, Göttingen, Copernicus GmbH (Copernicus Publications), XLII5, pp. 329 - 336 (proceedings of GEOMATICS \& RESTORATION - Conservation of Cultural Heritage in the Digital Era, Florence, 22-24 May 2017).

BORM, 2007. Ley 4/2007 de Patrimonio Cultural de la Región de Murcia, disposición transitoria primera. Boletín Oficial de la Región de Murcia (BORM).

https://www.boe.es/buscar/pdf/2008/BOE-A-2008-12526-

consolidado.pdf (13 de junio de 2019)

Cámara Muñoz A., 1990. Las torres del litoral en el reinado de Felipe II: una arquitectura para la defensa del territorio (I). In Espacio, Tiempo y Forma. Serie VII. Historia del Arte $\mathrm{n}^{\circ} 3$. UNED, pp. 55-86.

Cámara Muñoz, A., 1991. Las torres del litoral en el reinado de Felipe II: una arquitectura para la defensa del territorio (y II). In Espacio, Tiempo y Forma. Serie VII, Historia del Arte, $\mathrm{n}^{\circ} 4$. UNED, Madrid, España, pp. 53-94.

Collado, P.E.; García-León, J.; García, J.F., 2018. Estudio integral de la Torre Navidad, en Cartagena (España), para su correcta conservación, puesta en valor y musealización. In Defensive Architecture of the Mediterranean. Vol. IX. Politecnico di Torino, Torino, Italy, pp. 1179-1186.

General Direction of Cultural assets of the Autonomous Community of the Region of Murcia., 2019. Dossier of Negro Tower. Catalog Code 16257. Murcia, Spain.

García-León, J. Sánchez-Allegue, P. Peña-Velasco, C. Cipriani, L. Fantini, F., 2018. Interactive Dissemination of the 3DModel of a baroque Altarpiece: A pipeline from digital survey to game engines. SCIRES, Vol. 8, Issue 2, pp. 59-76. http://dx.doi.org/10.2423/i22394303v8n2p59

http://www.sciresit.it/article/view/13000

García-León, J.; Ros-Torres, J.; Vázquez Arenas, G.; Collado Espejo, P.E.; Pérez Navarro, J.; Ramos Martínez, M., 2019. Graphic survey and 3D virtual restoration of a $16^{\text {th }}$ century watch tower: Navidad Tower (Cartagena, Spain). In Advances on Mechanics, Design Engineering and Manufecturing II. Proceedings of the International Joint Conference on Mechanics, Design Engineering and Advanced Manufacturing (JCM 2018). Springer. Switzerland, pp. 242-251. 
Gómez Vizcaíno, A. Munuera Navarro, D., 2002 El sistema defensivo de los Austrias. In Estudio y catalogación de las defensas de Cartagena y su bahía. Dirección General de Cultura, Servicio de Patrimonio Histórico. Murcia, España, pp. 122-170.

Gómez Vizcaíno, A., 1997. Guía turístico-histórica de los castillos y fortalezas de Cartagena. Aforca D.L. (eds). Cartagena, España.

Gómez Vizcaíno, J.A. Martínez López, J.A. Munuera Navarro, D., 2003. Castillos y fortificaciones de la Comarca de Cartagena desde la época púnica hasta nuestros días. Ligia Comunicación. Murcia, España.

Pérez, L.M., 2007. El patrimonio defensivo del Mar Menor en época moderna y contemporánea: Torres, fortalezas y baterías. In Cartagena Histórica, julio-septiembre, $\mathrm{n}^{\circ}$ 20, Cartagena, España, pp. 4-18.

Remondino, F., 2011. Heritage Recording and 3D Modeling with Photogrammetry and 3D Scanning. Remote Sensing, 3, pp.1104-1138.

Rubio, J.M., 2000. Historia de las Torres vigía de la costa del Reino de Murcia (ss- XVI-XIX). Real Academia Alfonso X El Sabio. Murcia, España.

Spanish National Geographic Institute., 2019. Centro de Descargas del Instituto Geográfico Nacional. Gobierno de España.http://centrodedescargas.cnig.es/CentroDescargas/index. jsp (27 June 2019).

Velasco F., 2017. La construcción de torres de defensa en el litoral de Lorca, Mazarrón y Cartagena durante el siglo XVI. In MURGETANA n ${ }^{\circ} 136$, Año LXVIII. Academia Alfonso X El Sabio, Murcia. pp. 57-83.

Yastikli, N., 2007. Documentation of cultural heritage using digital photogrammetry and laser scanning. Journal Cultural Heritage, v. 8 n. 4, pp.432-427. En línea: http://www.sciencedirect.com/science/article/pii/S12962074070 01082 